\title{
名誉会員の、推 戴
}

4 月 2 日（水）の第 24 回通常総会（会場：福岡郵便眝金会館ホール）において，定 款第 9 条の規定に基づき，下記 5 氏が名举会員に推蔍され，松井会長から名誉会員証和 よびメダルが贈呈された(ご年齢順).

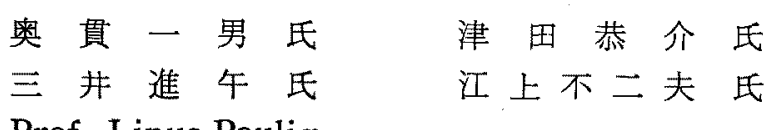

Prof. Linus Paulig

= 1 ス

\section{大平首相，味の素（株）川崎工場ご視察に寄せて}

去る 2 月 25 日，省エネルギー月間の政府公式行事と して，大平首相が味の素(株)川崎工場の省エネルギー活 動の実情をつぶさに視察された.とりわけ当工場の中权 的製造プラントであるグルタミン酸をはじめとする各種 アミノ酸，核酸系物質生産の発醅工場にご来場いたた きそそのプラントの責任者として，ご案内ょここでの省 エネルギー活動の実情についてご説明を申し上げる栄え ある機会に恵まれた。当川崎工場は敷地 35 万 $\mathrm{m}^{2}$, 従業 員約 1,400名で「味の素」に代表される各種調味料や医 薬用アミ〉酸類をはしめ食品, 医薬化成品の各分野の多 岐にわたる商品を生産しておら，そのエネルギー使用に ついても重油，電力ともども多量に及んでいる，そ机ゆ 充従来から省エネルギーへの取組みは活発で 48 年秋の 第一次石油ショックの折も，いち早く製造関係者を含め たメンパーによるエネルギー部会を設立し，工場全体の 省エネルギー活動の強化促進を図り，わずか 1 年半のう ちに約 15\%の土ネルギー削隇を実現した。乙かし 50 年

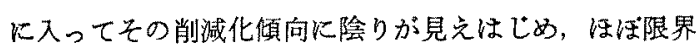
に達したときの考方方が強くなり，この限界を打破する ため従来の省土ネルギーの取組方法を根本から改めるぺ く、コンサルタント活用による systematic approach によるエネルギーの効率化プログラムを導入，KEEP活 動 (Kawasaki Energy Economizing Program) とし て工場ぐるみの取組みを展開，全員参加によるこの活動 を果敢に推進し予期以上の目覚しい成果を生みつつ今日 に至っている.ちなみ昭和 49 年をべースとした 54 年 までの当工場の省エネルギー活動の成果は, 工場全体と して実にエネルギー消費量の3割の削隇を達成した。こ のように当工場の省エネルギーへの取組みは今や対外的 にも高く評価され，たと光ば通産大臣賞をはじめ各方面 の表暗む多々受けるに至った。しかし基本的には，この
成果達成への道のりは一人一人のきわめて泥臭い, 地道 な努力の積重ねが中心であり，今回の政府公式行事とし ての首相視察の訪門先に選ばれたのも，なにはとるあれ 工場全員の常日頃のこの努力が認められ，高く評価され たゆえと受け止めている.さらにこの首相訪問に際し， グルタミン酸をはじめとする各種アミ，酸，核酸系物質 を発酵法で生産する世界最大級の当発醉プラントをとく につぶさに視察いただいたことは，われわれ発酵担当者 の感慨はさて置いても, 石油依存社会からの脱皮の切り 札として微生物工業が各方面から注目されている折柄だ けK，いっそら意義深いことと思ら次第である。

さてそこで，発酵法によるグルタミン酸をはじめとす る各種アミノ酸，核酸系物質の生産であるが，今やわが 国が世界汇誇り世界をりードする代表的工業分野となっ ていることは周知のことである.この種の発酵では, 複 雑多岥な反応が特定の微生物により常温常圧といらたい へ儿穏やかな条件で行われるが，使用する微生物だけを 純粹に培養しなければならず，工業生産的には大量の培 地の殺菌や装置類の殺菌等全工程にわたり充分な殺菌処 䁂を施す必要があり，この目的で多量の蒸気が四六時中 使われる，好気培盖ゆ占多量の無菌空気も必要であり， また培養中適温を保つために発酵熱を吸収する多量の冷 却水も必要である. 当然ながら培養のための強力な混合

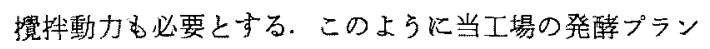
トむ，工場全体のエネルギー消費を大きく左右するエネ ルギー多消費部門である.ところで近来, 微生物育種技 術, 分析技術, 自動制御技術, 微生物化学工学など発醭 工業の周辺技術の進歩には目覚しいものがあり，「微生 物の魔術」の真価は遗澸なく発揮されつつあり，今後京 すます発展することる明らかである。そしてこれらの技 術の総合的, 有機的活用に上り, われわれの発酵工業は 
省エネルギー，省資源といら枠から一歩抜き出た「活資 源」といら前向さな幅広い発展を可能とするはずであ る、たとえば純粋培養を行らためのエネルギー消費量 は, 単位発酵槽当りほぼ一定と見てよい，そこで単位発 酵槽当りの生産量, すなわち目的生産物の蓄積濃度をい かに高く寸るか，あるいは一定基質からいかに高率で目 的生産物飞轱換するか溥心すれば，必然的飞省エネル ギー, 省資源での成果も達成される. 実はこのような考 えのもとに当発酵部門では先に記した職場の全員参加に よる省エネルギー活動 (KEEP) とあわせて，3 年ほど 前上り当社中央研究所, 工場技術部, 生産現場の 3 者が 一致協力して新技術の開発とその積極果敢な導入による 「活資源」活動を強力に推進し、目覚しい成果が出始め る炕至った．ちょらとここの時期化首相任直接われわれの これまでの努力や取組みの実状をご覧いただけたことは 望外の喜びとするところである.

首相ご来訪の当日は実にすがすがしい穩やかな晴天で あった．朝 8 時 40 分ご来場, 貴賓室にて工場長より, 当社执よび当工場の概要之省エネルギー活動の概況の説 明を受けられたのち, 白衣に安全へルメットの姿で, エ ネルギー庁, 内閣報導官, マスコミ関係者等総勢約 50 人の視察団とともに 9 時から約 20 分, 発酵工場を視察 された．首相は実に若々しい足取りで発酵プラントの中 央コントロール室へのタラップを一息に登られた，そこ のテラスから当社が誇るこの種の発酵槽として世界最大 級のタンク群を眺められ，熱心説明に耳を傾けられ た.

食品工場といらイメージよりむしろ化学工場といら印 象を強く受けられた様子で，一連の発醅槽群を錯綜する 各種パイプラインに驚かれていた，一見なんの変哲もな い発䤃槽の内部が総ステンレス製で, 純粋培養のため常 にピカピカに洗浄されていること, 酸素供給, $\mathrm{PH}$ 制御, 温度制御等がすべて無菌的に，自動的に作動する上う巧

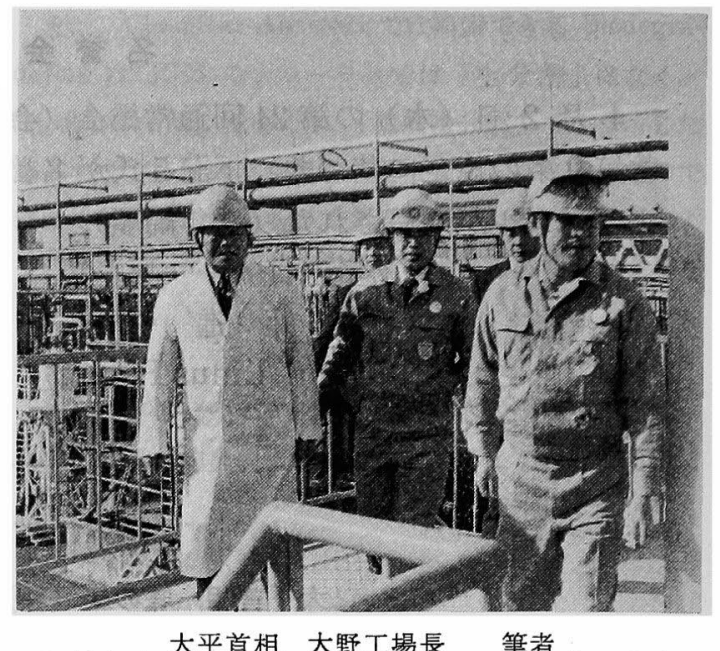

大平首相 大野工場長 筆者

妙な仕掛けが仕組まれていることを打話しすると感嘆さ れていた. 次いでコントロール室に入られ，一面の制御 パネルを見て「発酵部門だけの制御室ですか？」と目を 見張られた. ここでグラフを示しながら，当発酵部門の 省エネルギー活動の成果と，今後はますぬす技術革新が 必要で, われわれは単に省エネルギーの範囲に留まら ず，「活資源」という視点での活動を強力に進めて行き たい旨括し申し上け゚た。

「私はこらいう見学が大好きで，今日はほんとらに楽 しい.」と心底からお喜びの様子で 20 分余の発酵プラン トのご案内を終った. このあと当工場のユーティリティ 一センターを視察され公式日程を終え，次いで当工場従 業員約百名と民間テレピ局主催の対話集会を行い, 省エ ネ政策や外交問題, 物価, 防衛, 高龄化, 行政改革問題 など幅広い意見交換をなごやかな雾囲気のらちに約 1 時 間行ったが，その内容については本稿では割愛させてい ただく

（味の素(株)川崎工場製造第一課長 亀谷 清)

\section{日本であ始まったギンザヶの海中養殖}

日本語での，サケとマスの呼称には混乱がある. 姿や 形に違いがあって，それぞれ，サケと呼ばれたり，、ス と呼ばれたりするが，本来はいずれる北半球の海洋を回 游し，産卵のため遡河するサケ科の魚であって，それ ぞれの魚には名前ほどの違いはないらしい。このサケ科 の魚に特有の遡河性が，幾魚種かについて，湖沼型や河 川型と呼ばれる陸封型を分生した. 日本ではベニザケの 陸封型がヒメマスであり, サクラマスのとれがヤマメで あり, Onchorhyneus rhodurus の陸封型の湖沼型がビ
ワマスで, 河川型がアマゴとされている，英語の“Salmon”は, 日本語でのサケ，マスの名称と関係なく海産の サケ科の魚すべてを意味し，“trout”はニジマスなどの ような淡水産のサケ科の魚を指すようである.

サケ科の魚はサケ属 (Onchorhyncus), ニジマス属 (Salmo) 特よびィトウ属 (Hucho) の 3 属に分類され る. 英語で同じくサーモンと呼ばれてる, 北太平洋と北 大西洋では泳いでいるサケの属が違う.太平洋ザケはオ ンコリンクス属であり, 大西洋ザタはサルモ属である. 